\title{
LUBELSKA SZKOŁA METODOLOGII HISTORII W INSTYTUCIE HISTORII UMCS W LUBLINIE
}

Piotr WITEK, EWa SOLSKA,

\section{ABSTRACT}

\section{THE LUBLIN SCHOOL OF METHODOLOGY OF HISTORY AT THE UMCS INSTITUTE OF HISTORY IN LUBLIN}

The Department of Methodology of History and History of Historiography began functioning at Lublin's Maria Curie-Skłodowska University Institute of History in 1987. The establishment of the Department was initiated by Professor Jan Pomorski, who became its Head and has since held this position. Other faculty members are: Dr Ewa Solska, Dr Hab. Piotr Witek and Dr Hab. Marek Woźniak, Associate Professor.

The Department embraces historians, theorists of history science, methodologists of sciences, whose methodological style and training developed under influence of the Poznań Methodology School (Jerzy Topolski, Jerzy Kmita, Anna Pałubicka), Andrzej F. Grabski's model of history of historiography, Robert A. Rosenstone's visual history, the social constructivism of Nelson Goodman, Peter L. Berger and Thomas Luckman or Stanley Fish, the neopragmatism of Richard Rorty and Hilary Putnam, Thomas Kuhn's historicism, the poststructuralism of Roland Barthes and Michel Foucault, the hermeneutics of Hans Georg Gadamer and Paul Ricoeur, the cognitive grammar of George Lakoff and Mark Johnson, the narrativism of Hayden White and Franklin Ankersmit, Clifford Geertz's interpretive anthropology, and the tradition of the Lvov-Warsaw School (Alfred Tarski, Kazimierz Ajdukiewicz, Roman Ingarden) and analytical philosophy.

The teachers of the Department of Methodology of History conduct research in the following fields: methodology of history, history of historiography, neuroscience in the context of humanistic research, visual history, public history, digital humanities, cognitive science, and contemporary theories of literature. They conduct classes with students in methodology of history, history of historiography, history of philosophy, production of historical films, in designing historical games, knowledge of museums, and introduction to media studies.

The Department's faculty are co-originators and co-authors of programs taught at two specializations in historical studies: Management of Cultural Heritage and Commercialization of Historical Knowledge, and Applied History. Both specializations train and prepare students to practice history in the field of public history.

The teachers of the UMCS Department of Methodology of History together with its doctoral and graduate students effectively collaborate with many methodological and historiographical centers in Poland and abroad. They successfully develop and bring into effect Professor Jerzy Topolski's idea of the need to carry out theoretical reflection on academic historiography (research practice of historians), broadening it with considerations on public history.

\section{KEYWORDS:}

Department of Methodology of History, UMCS, Methodology of History. History of Historiography, Lublin 
Zakład Metodologii Historii i Historii Historiografii rozpoczął funkcjonowanie w Instytucie Historii Uniwersytetu Marii Curie-Skłodowskiej w Lublinie w 1987 roku. Inicjatorem powołania jednostki był prof. Jan Pomorski, który został jej kierownikiem i pełni tę funkcję do dnia dzisiejszego.

Zakład skupia historyków, teoretyków nauki historii i metodologów nauk, których metodologiczny sznyt kształtował się w perspektywie poznańskiej szkoły metodologicznej (Jerzy Topolski, Jerzy Kmita, Anna Pałubicka), modelu historii historiografii Andrzeja F. Grabskiego, historii wizualnej Roberta A. Rosenstone'a, społecznego konstruktywizmu Nelsona Goodmana, Petera L. Bergera i Thomasa Luckmana, Stanleya Fisha, neopragmatyzmu Richarda Rorty'iego i Hilarego Putnama, historyzmu Thomasa Kuhna, poststrukturalizmu Rolanda Barthes'a i Michela Foucaulta, hermeneutyki Hansa Georga Gadamera i Paula Ricoeur'a, gramatyki kognitywnej Georga Lakoffa i Marka Johnsona, narratywizmu Haydena White'a i Franklina Ankersmita, antropologii interpretatywnej Clifforda Geertza, oraz tradycji szkoły lwowsko-warszawskiej (Alfred Tarski, Kazimierz Ajdukiewicz, Roman Ingarden) i filozofii analitycznej.

W początkowym okresie istnienia Zakładu z prof. Pomorskim współpracowali dwaj badacze - Tomasz Pawelec i Andrzej Radomski'. Obecnie w Zakładzie obok prof. Jana Pomorskiego pracują trzy osoby: dr Ewa Solska, dr hab. Piotr Witek; dr hab. Marek Woźniak, prof. nadzw. ${ }^{2}$

1 * Tekst powstał na podstawie materiałów dostarczonych autorom przez pracowników Zakładu Metodologii Historii UMCS.

(1) Tomasz Pawelec jest uczniem profesora Pomorskiego. Prowadził badania nad naukową twórczością Marcelego Handelsmana. W 1992 roku obronił rozprawę doktorską poświęconą wybitnemu historykowi, a następnie na jej podstawie wydał książkę, która ukazała się drukiem pod tytułem: Myśl metodologiczna Marcelego Handelsmana, Lublin 1994. Niedługo po doktoracie Tomasz Pawelec odszedł z Instytutu Historii UMCS, by podjąć pracę naukową na Uniwersytecie Śląskiem w Katowicach.

(2) Andrzej Radomski jest uczniem Profesora Pomorskiego. Prowadził badania nad kulturologicznymi uwarunkowaniami praktyki badawczej historyków. W 1992 roku obronił pracę doktorską Metodologiczne problemy historii kultury na przykładzie wspótczesnej historiografii polskiej. Doktorat ukazał się drukiem w kształcie monografii noszącej tytuł: Kultura - Prawda - Poznanie, Lublin 1994. Pod koniec lat dziewięćdziesiątych opublikował książkę: Kultura Tekst - Historiografia, Lublin 1999. Praca jest przejawem fascynacji autora zwrotem postmodernistycznym w naukach humanistycznych i tekstologicznym podejściem do badań nad narracją historyczną. Na podstawie monografii Andrzej Radomski uzyskał stopień doktora habilitowanego. Niedługo po habilitacji odszedł z Zakładu Metodologii Historii i przeniósł się do nowopowstałego w UMCS Instytutu Kulturoznawstwa, gdzie powołał do istnienia Zakład Teorii Kultury i Metodologii Nauk o Kulturze.

2 Zakładem współpracują również inni uczniowie Profesora Pomorskiego: dr hab. prof. nadzw. Agnieszka Kolasa-Nowak z Instytutu Socjologii UMCS oraz dr hab. prof. nadzw. Anna Ziębińska-Witek z Instytutu Kulturoznawstwa UMCS. 
Profesor Jan Pomorski jest jednym uczniów prof. Jerzego Topolskiego, twórcy Polskiej Szkoły Metodologii Historii, którą rozwija i nadal kreśli jej przestrzeń doświadczenia oraz horyzonty oczekiwań.

W latach 1984-2005 profesor napisał trzy monografie autorskie, kilkaset artykułów naukowych, wiele publikacji popularnonaukowych, zredagował kilka tomów zbiorowych. Zainteresowania naukowe Jana Pomorskiego były i są nader wielostronne.

Początek kariery naukowej profesora wyznacza powstała na bazie rozprawy doktorskiej książka nosząca tytul $W$ poszukiwaniu modelu historii teoretycznej (Lublin 1984), w której autor zdradza fascynację scjentystycznym podejściem do humanistyki i historii w szczególności, aczkolwiek głównym zadaniem okazało się w niej rozpatrzenie procesu uteoretycznienia nauki historycznej jako zjawiska otwierającego przed historykami nowe możliwości prowadzenia badań, nieobecne w perspektywie historiografii deskryptywnej. Druga książka, będąca rozprawą habilitacyjną, nosi tytul Paradygmat 'New Economic History'. Studium z teorii rozwoju nauki (Lublin 1985). Wychodząc od koncepcji paradygmatycznej struktury nauki Thomasa Kuhna, autor rekonstruuje teoretyczne założenia amerykańskiego modelu nowej historii gospodarczej oraz świadomość metodologiczną historyków prowadzących badania na gruncie NEH. Obie prace miały charakter pionierski, prezentujący nowe (w czasie, kiedy zostały opublikowane) sposoby myślenia o historii oraz uprawiania badań historycznych. W trzeciej książce, zatytułowanej Historyk i metodologia (Lublin 1991), profesor powraca do refleksji nad statusem historiografii jako nauki. Czerpiąc inspiracje z Kuhnowskiej metodologii badań naukowych, postrzega historię jako dyscyplinę o strukturze paradygmatycznej. Wyróżnia przykładowe paradygmaty historiograficzne - historyzm, Szkołę Annales, New Economic History, marksizm, socialgeschichte. Wykazuje niezbędność metodologii dla praktyki badawczej historyków. Rozwija szereg kategorii analizy metodologicznej w historii. Prowadzi rozważania wokół problemów narracji historycznej oraz wizji świata i człowieka, wobec której sytuuje się każdy badacz próbujący poznać jakiś fragment przeszłości. Oprócz inspiracji historyzmem Kuhna obecne są tam również wpływy scjentyzmu metodologicznego Jerzego Topolskiego, wyłożonego w Teorii wiedzy historycznej (Poznań 1983), oraz metodologii nauk o kulturze Jerzego Kmity, znanej choćby z takich prac, jak Kultura i poznanie (Warszawa 1985), Wykłady z logiki i metodologii nauk (Warszawa 1976), Szkice z teorii poznania naukowego (Warszawa 1976) czy Z problemów epistemologii historycznej (Warszawa 1980).

Wrażliwość profesora na kulturologiczne podejście do badań historiografii sprawiła, że w orbicie zainteresowań znalazł się powstały w USA narratywizm, a wraz 
z nim, ufundowana na tradycji konstruktywistycznej, narratywistyczna filozofia historii, której głównymi przedstawicielami są Hayden White i Franklin Ankersmit. Jan Pomorski, publikując pod własną redakcją zbiorowy tom Metodologiczne problemy narracji historycznej (Lublin 1990), wprowadził do polskiej historiografii problematykę badań nad narracją w historiografii, pokazując nowy trend w metodologii i teorii historii. Dzięki wspomnianej monografii polscy historycy mogli także zapoznać się z przemyśleniami innych specjalistów $\mathrm{w}$ dziedzinie narratywizmu.

W kolejnych pracach Jana Pomorskiego coraz wyraźniej zarysowywały się wpływy społecznego konstruktywizmu. Z inspiracji konstruktywistycznych powstał też programowy i uchodzący obecnie za klasyczny artykuł: Historiografia jako autorefleksja kultury poznajaccej, w którym autor zdefiniował historię jako formę autorefleksji pokolenia i zapis samowiedzy kulturowej, utrwalony w postaci tekstów historiograficznych. Wpływy konstruktywizmu dostrzec można również w zredagowanych tomach zbiorowych: (1) Światooglądy historiograficzne (Lublin 2002), (2) Między modernizmem a postmodernizmem $w$ historiografii (Lublin 2005), w których widać również tropy zmagań ze zwrotem postmodernistycznym w humanistyce. Profesor Pomorski, dostrzegając w nim potencjał poznawczy wynikający z intelektualnego fermentu, który publikacje wprowadziły do refleksji historycznej i historiograficznej, jednocześnie pozostawał wobec nowych trendów krytyczny. Wyraz zdystansowanej postawie dał m.in. w głośnym artykule opublikowanym na łamach „Historyki”, zatytułowanym: Czy scjentyzm w historiografii końca XX wieku jest catkiem passé?

W obszarze zainteresowań metanauką odnośnie do badań historycznych pojawia się perspektywa kulturowa i społeczna. W pierwszym przypadku chodzi o antropologię historyczną i badania jej podstaw metodologicznych, w drugim o badania świadomości historycznej oraz społecznej funkcji historii. Ich owocem są zredagowane przez profesora Pomorskiego tomy: (1) Społeczna funkcja historii a wspótczesność (Lublin 1985), (2) W poszukiwaniu antropologicznego wymiaru historii: Aron Guriewicz i Carlo Ginzburg. Interpretacje (Lublin 1998), (3) Historia, metodologia, wspótczesność (Lublin 1998 ) oraz wiele artykułów publikowanych w czasopismach.

W badaniach nad historią najnowszą profesor Pomorski wiele miejsca przeznaczył spuściźnie Maison-Laffitte. Dzięki jego zaangażowaniu wielu historyków z UMCS, a także Uniwersytetu Łódzkiego mogło rozpocząć prace badawcze w Paryżu nad dorobkiem środowiska paryskiej Kultury. Na seminarium profesora powstawały rozprawy doktorskie poświęcone ludziom z kręgu Maison-Laffitte.

W orbicie zainteresowań prof. Pomorskiego znalazły się również badania nad uniwersytetem. Profesor jest w Polsce jednym z pionierów tego nurtu, inicjując 
pierwsze w naszym kraju seminaria i doktoraty w tej dziedzinie. Niemniej jednym z najważniejszych przedsięwzięć, będących modelowym przykładem badań w działaniu z tego obszaru, była organizacja Międzynarodowego Kongresu Rektorów Uniwersytetów Europejskich „Higher Education for United Europe”, który odbył się w Lublinie w dniach 28 kwietnia - 1 maja 2004 roku, z udziałem 300 rektorów z ponad 30 krajów Europy. Gospodarzem Kongresu, dzięki staraniom profesora Pomorskiego, ówczesnego prorektora ds. ogólnych, był Uniwersytet Marii Curie-Skłodowskiej. Zwieńczeniem tego wydarzenia stał się, ważny w kontekście europejskiej integracji w obszarze edukacji wyższej i badań naukowych, dokument pod nazwą „Deklaracja Lubelska”, ogłoszony 30 kwietnia 2004 roku, a stanowiący do dziś istotną wykładnię europejskiej kultury uniwersytetu.

W ostatnich kilku latach prof. Pomorski interesuje się neuronauką i wykorzystaniem jej ustaleń do badań prowadzonych na gruncie historii oraz innych dyscyplin humanistycznych. Efektem owych zainteresowań będzie książka Homo historicus, czyli człowiek jako sprawca historii. Według słów autora ma to być opowieść o tym w jaki sposób ustalenia współczesnej neuronauki i tzw. agency turn w naukach społecznych zmieniły jego podejście do interpretacji humanistycznej i jak powinny zmienić nasze myślenie o wytwarzaniu/stawaniu się historii samej. W związku z zainteresowaniami neuronauką prof. Pomorski organizuje również środowisko dla badawczej i dydaktycznej adaptacji tej stosunkowo nowej orientacji.

Wchodząc w nowe obszary akademickiej refleksji profesor Pomorski nie porzucił swoich dotychczasowych zainteresowań naukowych koncentrujących się na kulturologicznie zorientowanych badaniach metodologicznych nad historiografią. Owocem aktywności na tym polu jest ukończona właśnie książka zatytułowana Homo metahistoricus. Autor rozwija w niej swoją wcześniejszą tezę o historii jako autorefleksji kultury poznającej. Na monografię składa się zbiór rozpraw, dla których inspiracją do snucia własnych przemyśleń autora był namysł nad pracami innych teoretyków historii oraz rekonstrukcja i krytyczny rozbiór metodologii stosowanych w książkach stricte historycznych, które uzyskały szeroki rozgłos wśród odbiorców.

Aktualnie Jan Pomorski kontynuuje również swoje wcześniejsze zainteresowania naukowe związane z metodologiczną refleksją nad historią najnowszą. Podsumowaniem zmagań profesora z tym tematem ma być wielotomowa monografia Metodologia historii najnowszej. Teoria i praktyka, którą sam autor określa jako swoje opus magnum. Praca ma docelowo składać się z sześciu części: (1) Jak się pisze i rozumie historię najnowsza; (2) Wiek XX jako przedmiot poznania historycznego; (3) Polska historiografia dziejów najnowszych - subiektywny przegląd praktyk badawczych; (4) Polnische Historikerstreit 
czyli wielki spór o polską transformację; (5) Historia najnowsza. Między dyktatem pamięci i dyktatem polityki historycznej a wolnościa nauki; (6) Metodologia historii najnowszej. Podręcznik akademicki. Druk pierwszych tomów jest planowany na rok 2018, pozostałych części w roku 2019.

Najnowszym pomysłem prof. Jana Pomorskiego jest projekt napisania, jak sam autor powiada, „remake'u w dziedzinie historiografii” - monografii zatytułowanej Metahistory 2.0 The Historical Imagination in Nineteenth Century Poland. Do wspókpracy przy realizacji przedsięwzięcia zostały zaproszone trzy znakomite znawczynie historiografii polskiej XIX stulecia: prof. Katarzyna Błachowska (Uniwersytet Warszawski), prof. Violetta Julkowska (Uniwersytet im. Adama Mickiewicza) i prof. Jolanta Kolbuszewska (Uniwersytet Łódzki). Pomysł zakłada, że monografia ma być wyjściem poza to, co w swojej klasycznej już pracy Metahistory zrobił wybitny amerykański historyk Hayden White.

W 2017 roku nakładem Wydawnictwa UMCS ukazała się najnowsza książka Jana Pomorskiego: Spoglądając w przeszłość... Studia i szkice metahistoryczne, będąca swoistym autorskim podsumowaniem dotychczasowego naukowego dorobku profesora.

Jan Pomorski w Instytucie Historii prowadzi ze studentami szereg zajęć poświęconych metodologii.

Profesor na zajęciach seminaryjnych stara się uczyć metodologii metodą case studies, która polega w tym przypadku na analizach konkretnych prac historyków pod kątem rekonstrukcji zawartej w nich metodologii stosowanej. Metoda najlepiej sprawdza się na poziomie studiów doktoranckich. Profesor przywiązuje ogromną wagę do rozwijania umiejętności myślenia krytycznego i problemowego. Uczy tej umiejętności studentów i doktorantów sposobem polegającym na praktykowaniu zadawania pytań badawczych. Doktoranci na koniec pierwszego roku studiów mają za zadanie przedstawić rozbudowany konspekt rozprawy doktorskiej złożony wyłącznie z pytań. Według profesora jest to znakomite ćwiczenie z konceptualizacji przedmiotu badania/ poznania historycznego.

Specyfikę kursowego wykładu z metodologii historii i historii historiografii Jan Pomorski proponuje oprzeć na dwóch kwestiach: (1) konieczności kładzenia nacisku na to, że nie było nigdy i nie ma dziś czegoś takiego, jak jedna, uniwersalna nauka historyczna, uprawiana jakoby tak samo przez wszystkich historyków, a w konsekwencji podkreślaniu, że współczesna historiografia ma strukturę paradygmatyczną; (2) na organizacji egzaminu końcowego z przedmiotu, który u profesora polega na tym, że to nie on zadaje studentom pytania, lecz to oni przychodzą z gotowym pomysłem na pytania, które sobie zadają. Dzięki takiemu podejściu do egzaminu jego temat nie jest 
dla studentów zaskoczeniem, lecz szansą na pokazanie, jak rozumieją dane zagadnienie. Jan Pomorski stosuje tę praktykę od kilkunastu lat i jak sam twierdzi, niekoniecznie okazuje się ona łatwiejsza dla zdających. Pozwala jednak egzaminującemu o wiele więcej dowiedzieć się o egzaminowanym.

W kręgu zainteresowań naukowych Jana Pomorskiego, poza badaniami dokonań zawodowych historyków i teoretyków historii, znajduje się również historia pozaakademicka - public history. Problematyka historii publicznej jest podejmowana przez profesora od ponad dziesięciu lat na seminariach magisterskich, na których powstają innowacyjne prace magisterskie. Ich innowacyjność polega na tym, że wykraczają poza zaklęty krąg historii akademickiej. Jako przykłady profesor wymienia prace Adama Kwapińskiego o odtwórstwie historycznym, Piotra Kubasiewicza o historycznych grach komputerowych i ich wpływie na świadomość historyczną, Magdaleny Zawadki o obecności historii w tekstach współczesnych zespołów rockowych, Wojciecha Wabika o obecności teorii spiskowych w myśleniu studentów historii czy Tomasza Zdziebłowskiego o myśleniu spiskowym w społecznościach lokalnych na przykładzie Radzynia Podlaskiego, Michała Matejuka o formach obecności historii w prozie Andrzeja Sapkowskiego na przykładzie sagi o Wiedźminie, Magdaleny Dąbrowskiej i Magdaleny Kruszewskiej o dyskursie feminologicznym. Pracą innowacyjną pod względem formy był licencjat Pawła Brożka z roku 2009 przygotowany w postaci historycznego filmu dokumentalnego noszącego tytuł 4 czerwca 1989 roku w Lublinie. Podobnie innowacyjnym pomysłem była zainspirowana przez prof. Pomorskiego, pierwsza w Polsce, obrona pracy magisterskiej w formie widowiska rekonstrukcji historycznej pt. Lubelszczyzna 1944. Wyzwolenie czy druga niewola autorstwa Grzegorza Antoszka ${ }^{3}$. Z czytanych ostatnio lektur Jan Pomorski za cenne poznawczo uważa książki brytyjskiej socjolożki Margaret Archer. Za szczególnie ważne uznaje dwie monografie autorki: Structure, Agency and the Internal Conversation z roku 2003 oraz wydaną cztery lata później Making our Way through the World: Human Reflexivity and Social Mobility. Badaniom Archer wiele zawdzięcza koncepcja sprawstwa historycznego rozwijana przez profesora w omawianej wyżej książce Homo historicus. W ostatnich latach prof. Pomorski czyta również książki z historii najnowszej, które czyni przedmiotem swoich badań metodologiczno-historiograficznych. Wskazuje na dwa ważne tytuły. Są to jego zdaniem pozycje wybitne napisane przez dwie kobiety: PRL. Przedstawienia Joanny Krakowiak oraz Prywatyzując Polskę. O bobofrutach, wielkim biznesie i restrukturyzacji pracy Elizabeth Dunn.

3 Rekonstrukcja miała miejsce 19.07.2015 r. na terenie Muzeum Wsi Lubelskiej w Lublinie. Film wideo z obrony można zobaczyć na kanale YT: UMCS/ Instytut Historii TV: https://youtu.be/2yyXVYqF4Js. 
Dr hab. Piotr Witek jest uczniem profesora Pomorskiego. Pracuje w Zakładzie Metodologii Historii od roku 1995. Główny obszar naukowych zainteresowań tego badacza stanowią: metodologia i epistemologia historii; teoria i antropologia kultury; historia i teoria mediów ekranowych; zwrot audiowizualny w kulturze współczesnej; historia (audio)wizualna; historie niekonwencjonalne; historyczność współczesnej kultury; polityka historyczna. Prowadzone badania osadzone są w paradygmacie konstruktywistycznego modelu poznania.

Witek jest autorem dwóch monografii. Pierwsza z nich jest książkową wersją rozprawy doktorskiej obronionej w 2004 roku, która została zatytułowana: Kultura Film - Historia. Metodologiczne problemy doświadczenia audiowizualnego (Lublin 2005). Druga jest pracą habilitacyjną i nosi tytul: Andrzej Wajda jako historyk. Metodologiczne studium z historii wizualnej (Lublin 2016).

W pierwszej książce autor formuluje tezę, że film nie jest ani przy-językowy, ani przy-literacki, ani przy-historiograficzny. Jest autonomicznym wobec języka sposobem społecznego poznawania świata i oswajania historycznego doświadczenia audiowizualnego. Penetruje te obszary kulturowej rzeczywistości, które pozostają poza zasięgiem języka i pisanej narracji historycznej. Będąc terenem różnorakich orkiestracji intermedialnych, zjawiskiem kulturowym, skonstruowanym w oparciu o sąsiedztwo mediów, które zamienia na ich współistnienie, otwiera przed historykami nowe horyzonty doznań, doświadczeń i refleksji. Ma ogromny wpływ na zmianę naszych relacji z historią. Pozwala bowiem na myślenie o przeszłości i historii audiowizualnymi metaforami, a więc na innym, niezależnym od języka, poziomie abstrakcji i organizacji. Audiowizualne metaforyzowanie kulturowej rzeczywistości w filmie nie oznacza ucieczki od historii, jest raczej przeniesieniem jej na inne piętro refleksji. Dlatego zasadnym wydaje się być przekonanie, że film jest równorzędnym wobec historiografii sposobem społecznego oswajania historii, szerzej konstruowania historycznych światów możliwych i kulturowo uwarunkowanego poznawania świata. Z punktu widzenia przyjętego w pracy, film jest atrakcyjnym narzędziem re-produkowania treści społecznego historycznego doświadczenia audiowizualnego, „re-definiowania” istniejących kulturowych gier poznawczych, oraz projektowania nowych obszarów społecznego historycznego doświadczenia kulturowego.

W drugiej książce dr hab. P. Witek ukazuje historię wizualną jako rodzaj historii niekonwencjonalnej oraz przedstawia, jak w jej ramach ujmowany jest status i rola historyka. W tak nakreślonym kontekście stawia i uzasadnia tezę, że Andrzej Wajda jeden z najwybitniejszych polskich reżyserów filmowych, teatralnych i telewizyjnych może być uznany za historyka, a jego filmowe i telewizyjne dzieła za poważne narracje 
historyczne, które uczestniczą w publicznej debacie na temat przeszłości na równi z pracami i opiniami akademickich historyków. Książka składa się z metodologicznego wprowadzenia, trzech części stanowiących studium przypadków oraz zakończenia. W pierwszej części zostało podjęte zagadnienie historycznego filmu dokumentalnego i reprezentacji historii w filmie dokumentalnym Andrzeja Wajdy. W drugiej autor zajmuje się fabularnym filmem historycznym w kontekście twórczości wybitnego reżysera. Przedmiotem części trzeciej jest zagadnienie historycznego teatru telewizji w kontekście dzieł Andrzeja Wajdy. Analizowane w monografii filmy i telewizyjne widowiska reżysera, traktowane są nie jako dzieła sztuki i wytwory praktyki artystycznej, ale jako narracje historyczne będące alternatywnymi wobec akademickiej historiografii formami tworzenia wiedzy o przeszłości. Autor w książce skupia się na pokazaniu, jak w swoich filmach i telewizyjnych widowiskach Wajda rozumie historię, jakie historie przedstawia i jakimi metodami poznania i przedstawiania przeszłości się posługuje. W zakończeniu autor dokonuje podsumowania prowadzonych na kartach książki rozważań i postuluje, by wykorzystać szerokie perspektywy, jakie otwiera historia wizualna przed badaczami przeszłości związane z użyciem medialnych technologii w badaniach przeszłości przez profesjonalnych historyków ${ }^{4}$.

Piotr Witek jest autorem wielu artykułów z zakresu metodologii historii i historii wizualnej. W różnych tekstach rozwijał problematykę wykorzystywania filmu w funkcji narracji historycznej jako alternatywnej i równorzędnej opowieści o przeszłości w stosunku do prac pisanych na uniwersytetach przez zawodowych historyków. Zastanawiał się nad statusem filmu historycznego, w jakich okolicznościach dany film (dokumentalny/fabularny) staje się filmem historycznym oraz nad tym, czy film historyczny jest gatunkiem w sensie genologicznym. Skupiał się na analitycznym omówieniu cech charakterystycznych różnych formatów filmowego dokumentu historycznego. W wielu artykułach autor analizował różne filmy historyczne. Podejmował wątki etycznego aspektu przedstawień przeszłości na ekranie, szczególnie tzw. bieżącej historii, dziejącej się na naszych oczach. Zajmował się analizą użytych w narracji przez reżyserów strategii wykorzystania symboliki barw (kadrów i ujęć monochromatycznych oraz polichromatycznych) w funkcji metafor definiujących znaczenia poszczególnych scen w kontekście całej audiowizualnej opowieści historycznej. Badał obecne w rozmaitych filmach historycznych wzory estetycznych konwencji filmowych, np. takich jak - klasyczny dokumentalizm objaśniający, realizm magiczny, stylistyka filmów grozy - dzięki którym zrealizowane obrazy nabierały charakteru

4 W tym miejscu warto zwrócić uwagę, że jest to pierwsza w Polsce (i prawdopodobnie pierwsza na świecie) monografia w systematyczny sposób omawiająca zagadnienie statusu reżysera jako historyka na przykładzie Andrzeja Wajdy. 
dzieł auto-refleksyjnych. Badał historyczne obrazy fabularne, które uznawał za paradygmatyczne przykłady kina rozrachunkowo-refleksyjnego i martyrologicznoheroicznego, będące odpowiednio przejawami kina postnarodowej i narodowej pamięci historycznej. Podejmował się omówienia z perspektywy metodologicznej nowej subdyscypliny, którą jest historia wizualna, wyzwań jakie stawia przed historykami wytrenowanymi w paradygmacie kultury werbalnej oraz historii konwencjonalnej i tradycyjnej historiografii akademickiej. Podejmował zagadnienie konceptualizacji filmu jako źródła historycznego. Zajmował się również tym, w jaki sposób tzw. nowe cyfrowe media modelują historyczne światy przedstawione. W swoich pracach badacz podejmował również zadania konceptualizacji zjawiska polityki historycznej jako lokalnej i holistycznej inżynierii społecznej oraz krytycznej analizy debaty pomiędzy zwolennikami i przeciwnikami doktryny. Zajmował się analizą zjawiska ponowoczesnej temporalności i historyczności współczesnej zmediatyzowanej kultury. Skupiał się na krytycznej analizie świadomości metodologicznej historyków dziejów najnowszych, którzy w swoich tekstach deklarują, iż prowadzą namysł metodologiczny nad własną praktyką badawczą.

Piotr Witek jest współredaktorem kilku monografii zbiorowych. Pierwsza nosi tytuł Świat z historia (Lublin 2010) ${ }^{5}$. W książce zostały zamieszczone teksty, których autorzy proponują różne spojrzenia na uprawianie historii - od klasycznej historii historiografii po historię wizualną. Druga monografia nosi tytuł Historia w kulturze wspótczesnej. Niekonwencjonalne podejścia do przeszłości (Lublin 2011) i jest pokłosiem współorganizowanej przez Piotra Witka razem z dr Ewą Solską oraz prof. Mariuszem Mazurem ogólnopolskiej konferencji „Historie alternatywne”. Książka zawiera teksty omawiające współczesne niekonwencjonalne trendy badawcze na gruncie nauk historycznych (teoretyczne i metodologiczne problemy historii niekonwencjonalnej, historie wizualne, historie performatywne, sztuka i dziennikarstwo wobec przeszłości, alternatywne formy edukacji historycznej). Jest to pierwsza monografia w Polsce w systematyczny sposób podejmująca problem historii niekonwencjonalnych. We współpracy z lubelskim oddziałem IPN dr hab. Piotr Witek współredagował monografię zbiorową Klio na wolności. Historiografia dziejów najnowszych w Polsce po 1989 roku (Lublin 2016). Książka jest pokłosiem ogólnopolskiej konferencji „Historiografia dziejów najnowszych w Polsce po 1989 r. Problemy. Wyzwania. Dylematy” zorganizowanej razem z prof. Mariuszem Mazurem (UMCS), prof. Sławomirem Łukasiewiczem (KUL/ IPN), dr. Sławomirem Poleszakiem (IPN) i dr. hab. Marcinem Kruszyńskim (IPN). Monografia składa się z tekstów najwybitniejszych przedstawicieli polskiej

5 Współredaktorem książki jest Marek Woźniak. 
historiografii, podsumowujących dokonania historyków dziejów najnowszych, historyków historiografii oraz metodologów historii w ostatnich 25 latach, po odzyskaniu przez Polskę suwerenności w roku 1989. W 2017 roku ukazały się kolejne monografie zbiorowe pod red. Piotra Witka, Ewy Solskiej i Marka Woźniaka. Są to: Historiografia w kontekstach nieoczekiwanych? Wobec zmiany i ciagtości: pejzaże wspótczesnego dyskursu historycznego (Lublin 2017); Historie alternatywne i kontrfaktyczne. Wizje - Narracje - Metodologia (Lublin 2017); Między nauka a sztuką. Wokót problemów wspótczesnej historiografii (Lublin 2017). Wszystkie trzy monografie podejmują wątki związane $\mathrm{z}$ badaniem profesjonalnej historiografii oraz alternatywnych wobec akademickiej historiografii form refleksji historycznej.

Aktualnie Piotr Witek pracuje nad nową książką autorską, która będzie podejmować problematykę metodologii historii wizualnej.

Dr hab. Piotr Witek w Instytucie Historii prowadzi ze studentami zajęcia z metodologii nauk społeczno-humanistycznych, historii wizualnej, historii cyfrowej, muzeów historycznych, wstępu do medioznawstwa. Jest współpomysłodawcą i współautorem programu prowadzonej na pierwszym stopniu studiów historycznych specjalizacji: Zarzadzanie dziedzictwem kulturowym i komercjalizacja wiedzy historycznej oraz pomysłodawcą i autorem programu specjalizacji prowadzonej na studiach magisterskich: Historia stosowana. Na obu specjalizacjach studenci są kształceni i przygotowywani do uprawiania historii w obszarze public history.

Na zajęciach z historii wizualnej, historii cyfrowej oraz z muzeów historycznych studenci nabywają umiejętności interpretacji i krytycznej analizy audiowizualnych przekazów medialnych - filmów historycznych, historycznych widowisk telewizyjnych, radiowych i telewizyjnych programów historycznych, historycznych gier komputerowych, portali i wortali zajmujących się problematyką historyczną. Na zajęciach stosowana jest metoda case studies, która polega w tym przypadku na analizach konkretnych przykładów kina historycznego, historycznych widowisk telewizyjnych, ekspozycji muzealnych, itd., pod kątem zawartych w nich treści oraz form i stylów przedstawiania przeszłości. Szczególny nacisk jest kładziony na estetykę przedstawień, która implikuje treść, co oznacza, że kiedy analitycznie odróżnimy styl i treść, możemy przypisać stylowi pierwszeństwo nad treścią - mówiąc jeszcze inaczej, treść jest w tym przypadku pochodną stylu - formy.

Na zajęciach z historii wizualnej prowadzonych przez Piotra Witka studenci uczą się również pisania scenariuszy i scenopisów filmowych oraz realizacji filmu historycznego (praca z kamerą, postprodukcja). Na zakończenie kursu, aby uzyskać zaliczenie z przedmiotu, muszą zrealizować własny kilkuminutowy film. Na zajęciach 
z historii cyfrowej studenci uczą się różnych strategii kreowania cyfrowych opowieści historycznych (digital story telling) z wykorzystaniem rozmaitych aplikacji. Na zaliczenie przedmiotu muszą stworzyć i prowadzić przez cały okres kursu własny blog, portal, kanał na YouTube podejmujący tematykę historyczną.

Wszystkie zaliczeniowe prace studentów zrealizowane na zajęciach $\mathrm{z}$ historii wizualnej i cyfrowej zaliczają się do innowacyjnych ze względu na to, że wychodzą poza obszar historii akademickiej i stanowią dla niej realną alternatywę. Przykładowe filmy studentów: Smok. Bestia czy bohater? (Real. Paulina Gajek, Jarosław Michota); Przedostatni Legion, (Real. Dominik Binienda, Aleksandra Grosicka, Bartłomiej Nowak, Ewelina Orłowska) Jawa czy sen? (Real. Karolina Sternik, Iwona Górnicka, Bartłomiej Chudy i Jarosław Ochnio); Statesman (Real. Grzegorz Bednarczyk, Mateusz Kubicki); Nostalgia Rejowca (Real. Bartłomiej Ważny); Poemat o mieście Lublinie (Real. Karolina Misztal, Dorota Ręba, Andrzej Misztal); Legenda o Boczarskim (Real. Cyprian Perepeczo i Sylwia Suszko); Based On a True Story Opowieść o 1000 i jednej śmierci (Real. Patryk Płokita i Andrzej Dąbrowski) i wiele innych można obejrzeć na prowadzonym przez Piotra Witka kanale YouTube: UMCS/ Instytut Historii TV na playliście - Etiudy studenckie.6 W kontekście innowacyjnych dokonań studentów na szczególną uwagę zasługuje wspomniany wyżej projekt dwóch studentów Patryka Płokity i Andrzeja Dąbrowskiego, których film jest wideoklipem do utworu ich autorstwa. Obaj panowie z inspiracji Piotra Witka założyli zespół muzyczny BOaTS (Based on a True Story) wykonujący rap historyczny. Tworzą własną muzykę, piszą teksty o tematyce historycznej, realizują wideoklipy. Aktualnie przygotowują materiał do wydania pierwszej plyty.

Piotr Witek jest również pomysłodawcą projektu E-TV Historia. W założeniu ma to być prowadzona przez studentów i doktorantów internetowa telewizja historyczna stanowiąca alternatywę dla mainstreamowych mediów historycznych, w której młodzi historycy będą realizować własne przedsięwzięcia. Projekt jest realizowany razem z dr Ewą Solską i studentami z koła metodologicznego - Pauliną Gajek, Jarosławem Michotą, Andrzejem Włochem, Gabrielą Winiarczyk, Janem Szajowskim.

Praca naukowa Piotra Witka czerpie inspiracje z szeregu różnorodnych lektur. Na szczególną uwagę zasługują książki Roberta A. Rosenstone’a, amerykańskiego historyka, który jako jeden z pierwszych, jeszcze w latach osiemdziesiątych dwudziestego stulecia, zajął się na poważnie badaniem filmu jako alternatywnej wobec historiografii formy refleksji historycznej. Są to: (1) Visions of the past. The Challange of Film to Our Idea of History, Cambridge, Massachusetts, London, England 1995; (2) History on Film. Film

6 https://www.youtube.com/playlist?list=PLIqTA7rsIGNmpOX4gzYKFjTE1KXTfGF5z [Dostęp: 10-11-2017]. 
on History, London, New York, Boston, San Francisco, Toronto, Tokyo, Singapore, Hong Kong, Seoul, Taipei, New Delhi, Cape Town, Madrid, Mexico City, Amsterdam, Munich, Paris, Milan: Pearson Longman, 2006. W kontekście prowadzonych przez dra Witka badań warto jeszcze wskazać na prace dwóch medioznawców i antropologów. Do pierwszej grupy zaliczają się książki Lva Manovicha, Język nowych mediów oraz Henry Jenkinsa, Kultura konwergencji. Zderzenie starych i nowych mediów. Do drugiej prace Sarah Pink, Etnografia wizualna. Obrazy, media i przedstawienie w badaniach, Andre Roille, Fotografia. Między dokumentem a sztuka spoteczna oraz Hansa Beltinga, Antropologia obrazu. Szkice do nauki o obrazie. Za istotne ostatnio prace z zakresu teorii historii uznaje P. Witek książki niemieckich autorów: Jorna Rusena, Myślenie historyczne. Nadawanie historycznego sensu oraz Reinharta Kosellecka, Warstwy czasu. Studia z meta-historii.

Marek Woźniak jest uczniem profesora Pomorskiego. Z zakładem związany jest od roku 1997, w którym podjął studia doktoranckie. Po ich ukończeniu został zatrudniony na stanowisku adiunkta. Obecnie piastuje funkcję profesora nadzwyczajnego.

Prof. nadzw. Woźniak jest autorem dwóch monografii. Pierwsza jest książkową wersją doktoratu i nosi tytuł: Doświadczanie historii. Kulturowy i społeczny wymiar mitu rewolucji, Wydawnictwo UMCS, Lublin 2003. Druga jest pracą habilitacyjną zatytułowaną: Przeszłość jako przedmiot konstrukcji. O roli wyobraźni w badaniach historycznych, Wydawnictwo UMCS, Lublin 2010. Badacz jest także redaktorem i współredaktorem wielu tomów zbiorowych oraz autorem kilkudziesięciu artykułów. W swoich pracach podejmuje problematykę z zakresu metodologii historii i historii historiografii: mit rewolucji, poznawczy status wyobraźni historycznej, źródło historyczne, pamięć, historia kontrfaktyczna ${ }^{7}$.

Dr Ewa Solska jest związana z Zakładem Metodologii Historii od studiów doktoranckich rozpoczętych w roku 2003. Po ich ukończeniu została zatrudniona na stanowisku adiunkta. W obszarze jej zainteresowań naukowych znajdują się: ogólna metodologia nauk, metodologia historii, współczesne teorie poznania historycznego, historia filozofii, filozofia nauki, antropologia kultury, historia historiografii, historie niekonwencjonalne, współczesne teorie literatury, współczesne badania nad nauką i technologią, humanistyka cyfrowa, kognitywistyka. Ewa Solska jest autorką jednej monografii oraz kilkudziesięciu artykułów naukowych opublikowanych w czasopismach i tomach zbiorowych, a także współredaktorką pięciu monografii zbiorowych. Obecnie pracuje nad książką poświęconą zagadnieniu kultury naukowej.

7 Szczegóły na temat bibliografii i aktywności Marka Woźniaka można znaleźć na jego uniwersyteckim profilu pod adresem: http://www.umcs.pl/pl/addres-book-employee,3069,pl.html [Dostęp: 10.11.2017]. 
Monografia autorska pt. Duch liberalizmu a projekt Europejskiej Przestrzeni Edukacyjnej (Lublin 2011) to książkowa wersja rozprawy doktorskiej i jedna z pierwszych w Polsce prac w nurcie badań nad uniwersytetem. Autorka wg zasad teorii ugruntowanej analizuje europejski proces integracyjny w obszarze edukacji wyższej (tzw. proces boloński), formując koncepcyjne zręby projektu EHERA (European Higher Education and Research Area) w kontekście dtugiego trwania tego, co określa jako „kultura uniwersytetu”. Przy czym pokazuje jak metaforyczny „duch liberalizmu”, odnoszący się z jednej strony do globalnych trendów na „rynku wiedzy”, z drugiej „otwartego dostępu” w polityce naukowej i edukacyjnej, odzwierciedla się w przestrzeni akademickiej i samego uniwersytetu jako modelu instytucjonalizacji skorelowanych obszarów badań-nauczania.

W przygotowywanej obecnie rozprawie habilitacyjnej (Kultura naukowa. Dyskurs - projekt - integralność) kilka istotnych wątków pierwszej monografii znajduje swoje rozwinięcie m.in. w kwestiach: polityki naukowej, instytucjonalizacji badań, komunikacji wiedzy, dyskursu meta-nauki, sporu o humanistykę, projektu oświeceniowego i historyczności dyskursu naukowego oraz postulatu europejskości jako sytuacji kultury naukowej. Względem tych zagadnień kształtuje się i rozwija w różne kierunki problematyka poruszana przez Solską w artykułach z zakresu szeroko pojętej metodologii, którą autorka ujmuje modelowo w trzech wymiarach badań nad nauką: teorii (tzw. języka nauki) - metody (i metodyki) - oraz instytucjonalizacji (organizacji) nauki, dołączając perspektywę historyczną. W tym kontekście szczególne zainteresowanie aksjologią badań naukowych oraz tym, co nazywa apologią (obroną) upraktycznienia i postulatem oświeceniowym względem nauki w przestrzeni publicznej (w szczególności public humanities i public history). Stąd próba reaktywacji sporu o ideę magistra vitae w skorelowaniu jej m.in. z dyskursem historii alternatywnych.

Solska okazuje się konsekwentną uczennicą Prof. Pomorskiego względem prawie równie entuzjastycznego podejścia do modelu badawczo-wdrożeniowego humanistyki współczesnej; w obszarze nauki historii przekłada się to na zainteresowanie projektem historii stosowanej, zwłaszcza w odniesieniu do nowych technologii i modeli komunikacji wiedzy; modus art based research-research based art, wizualizacja oraz audiowizualne źródło historyczne są dla niej w tym obszarze kluczowymi tropami konceptualizacji. Nie jest zatem tak, że w swoim zaangażowaniu w „upraktycznienie” dyskursu humanistycznego, w szczególności nauki historii dr Solska zaniedbuje obszar refleksji teoretycznej i metodologicznej. Zresztą bieżące publikacje poświęcone m.in. tematyce rekonstrukcji, koncepcji (post)analitycznej filozofii historii, poezji cybernetycznej (Czy Platon wyświęcałby poetów cybernetycznych?), humanistyki cyfrowej 
jako meta-orientacji badań humanistycznych, a także case studies z obszaru historii komemoratywnej (Komemoracja w społeczeństwie sieciowym. Dyskursywne konsekwencje projektu „Henio on Facebook”), świadczą o tym, że gotowa będzie bronić istotnej poznawczej, kulturowej i społecznej celowości teorii naukowej.

Kolejne etapy rozwijania tematyki badawczej w stronę obecnie opracowywanej koncepcji kultury naukowej odzwierciedlają się w dziełach redagowanych przez p. doktor, począwszy od monograficznego numeru „Kultura i Historia” ( $\mathrm{nr}$ 10/2006) poświęconego badaniom nad uniwersytetem. Współredagowane wydawnictwa książkowe: Historia w kulturze wspótczesnej. Niekonwencjonalne podejścia do przeszłości (2011); Humanistyka Cyfrowa. Badanie tekstów, obrazów i dźwięku (2016), Historiografia w kontekstach nieoczekiwanych? Wobec zmiany i ciagtości: pejzaże wspótczesnego dyskursu historycznego (2017), Historie alternatywne i kontrfaktyczne. Wizje - narracja metodologia (2017), Między nauką a sztukq - wokót problemów wspótczesnej historiografii (2017) wydają się układać w dość spójny choć zdecydowanie niepełny jeszcze obraz pewnej wizji teoretyczno-metodologicznej, która stanowi o specyfice lubelskiej szkoły metodologicznej.

Ewa Solska prowadzi zajęcia na Wydziale Humanistycznym ze studentami ${ }^{8}$ Instytutu Historii, Instytutu Filologii Polskiej, Instytutu Filologii Słowiańskiej oraz Zakładu Logopedii i Językoznawstwa Stosowanego. Była jednym z wykonawców grantowego projektu „UMCS dla rynku pracy i gospodarki opartej na wiedzy”, wspólfinansowanego ze środków Unii Europejskiej w ramach Europejskiego Funduszu Społecznego z Programu Operacyjnego Kapitał Ludzki 2007-2013: „Wzmocnienie potencjału dydaktycznego uczelni”. Owocem tego przedsięwzięcia jest m.in. utworzona na pierwszym stopniu studiów historycznych specjalizacja: Zarządzanie dziedzictwem kulturowym i komercjalizacja wiedzy historycznej. Solska partycypowała także w tworzeniu programu specjalizacji prowadzonej na studiach magisterskich: Historia stosowana. Studia te koncentrują się na teoretycznym i praktycznym przygotowaniu adepta do pracy w obszarze public history / public humanities. Konsekwentnie zatem na wszystkich zajęciach ze studentami dr Solska stosuje metodykę multimedia based education, zasadę interaktywności oraz regułę rozszerzania przestrzeni edukacyjnej (m.in. wyjścia do muzeów, zewnętrzne uczestnictwo w tematycznych spotkaniach i prelekcjach, udział w obradach konferencyjnych, zapraszanie na debaty uniwersyteckie pracowników zewnętrznych instytucji edukacyjno-kulturowych).

Jak przedstawia się tematyka zajęć dydaktycznych dr Solskiej? Wykład z gatunków opowieści historycznych zaczyna się od współczesnych teorii literatury, koncentrując

8 Tu od razu należy dodać, że dr Solska z reguły przedstawia się jako nauczycielka akademicka, a znajomym na forach społeczościowych donosi, że nauczycielstwo uważa za swoje powołanie. 
się na modelach historiografii oraz (historycznych i współczesnych) gatunkach dziejopisarstwa. Uwydatnia w tym ujęciu historie niekonwencjonalne, eksperymenty i strategie narracyjne oraz nowe zjawiska i trendy w uprawianiu historii. Z kolei zajęcia z muzeologii obejmują dzieje muzeum jako instytucji publicznej, aspekty prawne systemów wystawienniczych, zarządzanie placówką muzealną, podstawowe zagadnienia dotyczące ekspozycji; narracja-rekonstrukcja-spektakl, memorial a historial, public history oraz muzeum krytyczne - to zasadnicze wątki tematyczne tego konwersatorium.

Historia historiografii jest już tradycyjnym wykładem i konwersatorium dla wszystkich specjalności studiów historycznych. Dr Solska prowadzi je dla pierwszego roku studiów magisterskich w Instytucie Historii. Poza kwestią genezy, chronologicznym przebiegiem rozwoju i przemian metodologicznej specyfiki historiografii na zajęciach porusza następujące zagadnienia: filozoficzne instrumentarium dyskursu historycznego; kategorie analizy metodologicznej w dyskursie historycznym; jak się pisało i rozumiało historię - dzieje historiografii w analizie systematycznej; linguistic turn i konstruowanie narracji historycznej; historia uczona po zwrocie post-scjentystycznym, koncepcja alternatywnych podejść do przeszłości, dyskurs „końców historii” i historia alternatywna.

Przedmiot „Współczesne modele historiografii w praktyce turystycznej” wykładane na kierunku Turystyka Historyczna koncentruje się na współczesnych teoriach poznania historycznego i narracyjnych modelach dziejopisarstwa, które turystolog będzie mógł wykorzystać w praktyce turystyki kulturowej. Istotnym wątkiem są tu tropy meta-historyczne w odniesieniu do teorii i praktyk turystycznych: zwroty, przesunięcia paradygmatyczne, nowe nurty, orientacje, postulaty metodologiczne.

Wykład z metodologii badań naukowych koncentruje się na wiedzy o nauce i jej funkcjach jako dziedziny kultury i formy wiedzy. Eksponowane są zagadnienia następujące: typy nauk (odmienności metodologiczne); wyjaśnianie naukowe - modele; teorie w nauce; status poznawczy nauki oraz STS (Science-Technology Studies) jako model badań nad nauką. $Z$ kolei wykład z historii filozofii przybliża najważniejsze problemy w dziejach filozofii europejskiej w tym aktualne spory wokół kwestii teoriopoznawczych (m.in. pojęcia prawdy, wiedzy, kwestii relatywizmu, sporu: naturalizm/sceptycyzm). Prezentowane są główne prądy filozoficzne kształtujące kulturę poszczególnych epok, najważniejsze stanowiska i postaci. Natomiast zajęcia konwersatoryjne ze wstępu do socjologii przybliżają problematykę badań socjologicznych w perspektywie historycznej i metodologicznej. Wśród wybranych wątków problemowych następujące: globalizacja, procesy globalne, globalne nierówności, migracje; struktury społeczne i ruchy społeczne; organizacje i sieci; media; wojna i terroryzm; religia; kwestie ekologiczne w socjologii. 
Konwersatorium z informatyki i informatologii koncentruje się na przybliżeniu podstawowych pojęć informatyki, data science oraz na zagadnieniach z zakresu naukoznawstwa, socjologii sieci, prawa internetu i humanistyki cyfrowej. Ogólna wiedza o programowaniu i przetwarzaniu informacji, multimediach oraz sieciach komputerowych celuje w stronę wzmacniania kompetencji adeptów w posługiwaniu się nowoczesnymi technologiami informacyjnymi w zakresie komunikacji naukowej. Wreszcie wykład z prawa autorskiego, który obejmuje szeroko ujętą tematykę prawa własności intelektualnej oraz kwestie umów prawno-autorskich i odpowiedzialności (cywilnej i karnej) z tytułu naruszenia praw autorskich.

Ewa Solska wykorzystuje od początku pracy naukowej i pedagogicznej na UMCS swój potencjał organizacyjny. Spośród przedsięwzięć realizowanych indywidualnie lub razem z Kołem Metodologicznym Historyków warto przypomnieć: ogólnopolskie debaty tematyczne w Instytucie Historii UMCS (cyklicznie od roku 2009), konkurs dla maturzystów "Historiomania - w drogę na studia" (2009) oraz koordynację udziału KMH w „Konkursie na projekt”, organizowanym w 2011 roku przez biuro poselskie p. Poseł do Parlamentu Europejskiego prof. Leny Kolarskiej-Bobińskiej, na rzecz rozwoju wiedzy i promowania Lubelszczyzny. Studenci pod opieką dr Solskiej przygotowali projekt: „Lubelszczyzna - Wiele kultur - wiele możliwości”, który otrzymał drugą nagrodę. Pokłosiem tego przedsięwzięcia była min. organizacja wraz z KMH i Biurem Poselskim prof. Kolarskiej-Bobińskiej konkursu dla licealistów - na krótki film o tematyce historyczno-regionalnej p.n. „Stąd jestem, tu zostaję”.

Dr Solska organizowała również kilka konferencji naukowych na UMCS, w tym: ogólnopolską konferencję „Historie Alternatywne” (17-19 maja 2010 r.) razem z dr Piotrem Witkiem i prof. Mariuszem Mazurem z Zakładu Historii Najnowszej; ogólnopolską konferencję „Tymoteusz Karpowicz: Ostatni modernista, ojciec poezji lingwistycznej, patron twórców osobnych - czy postać znowu nierozpoznana?” (28-30 maja 2012r.) razem z mgr Agatą Ptak z Instytutu Filologii Polskiej KUL; ogólnopolską konferencję naukową: „Humanistyka cyfrowa - badanie tekstów, obrazów i dźwięku” [w ramach cyklu DARIAH-PL „Nowoczesne technologie w badaniach humanistycznych], zrealizowaną razem z prof. Andrzejem Radomskim i dr Radosławem Bombą z Instytutu Kulturoznawstwa UMCS oraz Międzynarodowe Seminarium Metodologiczne: „Historiografia w kontekstach nieoczekiwanych. W stronę Prześnionej rewolucji A. Ledera i Fantomowego ciała króla J. Sowy”, w Instytucie Europy Środkowo-Wschodniej w Lublinie [w cyklu zjazdów Towarzystwa Historiograficznego] (24-25 września 2015 r.). 
W pracy naukowej i dydaktycznej Ewa Solska czerpie inspiracje z szerokiego spektrum lektur, aczkolwiek obecny dobór podporząakowany jest problematyce rozprawy habilitacyjnej i zainteresowaniom w polu nauk kognitywnych i humanistyki cyfrowej. Wśród opracowań na ten temat m.in. Between Philosophy and Science, M. Heller et all eds., Copernicus Center Press, Warszawa 2013; W. Drees, Nauka wobec wiary. Spory, debaty, konteksty, przeł. K. Skonieczny, Copernicus Center Press, Warszawa 2016; P. Burke, Spoteczna historia wiedzy, przeł. A. Kunicka, Aletheia, Warszawa 2016; Ł. Afeltowicz, Modele, artefakty, kolektywy. Praktyka badawcza w perspektywie wspótczesnych studiów nad nauka, Wydawnictwo Naukowe UMK, Torun 2012; H-J. Rheinberger, Epistemologia historyczna, przel. J. Surman, Oficyna Naukowa, Warszawa 2015; T. Barthscherer, R. Coover, Switching Codes: Thinking through Digital Technology in the Humanities and the Arts, University of Chicago Press, Chicago 2011; J. McGann, A New Republic of Letters: Memory and Scholarship in the Age of Digital Reproduction, Harvard University Press, Cambridge 2014; Mateusz Hohol, Wyjaśnić umyst, Struktura teorii neurokognitywnych, Copernicus Center Press, Warszawa 2013; Metodologiczne i teoretyczne problemy kognitywistyki, pod red. Jana Woleńskiego, Andrzeja Dąbrowowskiego, Copernicus Center Press, Warszawa 2014; Daniel Dennett, Dźwignie wyobraźni i inne narzędzia do myślenia, przel. Ł. Kurek, Copernicus Center Press, Warszawa 2015.

Dr Solska stale powraca do lektur, które uznaje ze swojej perspektywy za kanoniczne we współczesnej humanistyce europejskiej i zaleca do czytania w ramach zajęć kursowych swoim studentom. Wśród nich m.in.: Roberto Calasso, Zaślubiny Kadmosa z Harmonia, przeł. S. Kasprzysiak. Warszawa 1988; Georg Steiner, Gramatyki tworzenia, przeł. Jerzy Łoziński, Poznań 2004; Michel Foucault, Historia seksualności, przeł. B. Banasiak i in., słowo/obraz terytoria, Gdańsk 2010; J-F. Lyotard, Poróżnienie, przeł. B. Banasik, Wydawnictwo Uniwersytetu Jagiellońskiego, Kraków 2010; Alain Badiou, Byt izdarzenie, przeł. P. Pieniążek, Kraków, Eidos, 2010; S. Žižek S. W obronie przegranych spraw, przeł. J. Kutyła, Wydawnictwo „Krytyki Politycznej” Warszawa 2008; Marcin Polak, Trauma bezkresu, Universitas, Kraków 2016; John B. Barrow, Książka o niczym. Od pustki Greków, przez zero Babilończyków i nicość Hindusów, po próżnię kwantowa wspótczesnej nauki, przeł. Ł. Lamża, Copernicus Center Press, Warszawa 2015; Walter B. Michaels, Ksztatt znaczacego, przeł. J. Burzyński, korporacja ha!art, Kraków 2011; Maria Janion, Do Europy - tak, ale razem z naszymi umarlymi, Wydawnictwo Sic!, Warszawa 2000.

Do głównych kierunków badań w przeciągu 30 lat działalności lubelskiego Zakładu Metodologii Historii należą: Miejsce i rola Zeszytów Historycznych w powojennej historiografii polskiej: refleksja teoretyczna i historiozoficzna na łamach paryskiej Kultury i Zeszytów Historycznych; Recepcja myśli historiozoficznej Zeszytów 
Historycznych w historiografii polskiej; Myśl metodologiczna historyków polskich; Między nauką a sztuką - filozoficzne i metodologiczne problemy współczesnej historiografii; Historiografia a literatura - narracja historyczna jako meta-powieść; Historiografia a fotografia i film - metodologiczne problemy doświadczenia audiowizualnego; Multimedialny przekaz historyczny; Feminizm i historia mentalności; Niekonwencjonalne podejścia do przeszłości; Miejsce i rola Uniwersytetu w kulturze współczesnej; Liberalizm - przeszłość, teraźniejszość, przyszłość; Kognitywistyka jako meta-orientacja metodologii historii.

W 2014 roku przy Zakładzie powstało lubelskie koło Towarzystwa Historiograficznego. Jego działalność realizuje statutowe cele Towarzystwa (w tym: inspirowanie i organizowanie badań z zakresu historii historiografii, metodologii historii, teorii wiedzy i kultury historycznej, dziejów edukacji historycznej oraz społeczne upowszechnianie ich wyników. Programowo wpisuje się także w tworzenie i promowanie nowych ścieżek innowacyjnego zastosowania zasobów wiedzy w ramach prac badawczo-wdrożeniowych dla badań historycznych. Koło skupia pracowników naukowych i doktorantów UMCS i KUL, pracowników IPN, a także absolwentów naszych uniwersytetów działających w obszarze sektorów przemysłu kreatywnego. Oto kierunki projektowania aktywności tego podmiotu:

- Cykliczne debaty z udziałem osobistości świata nauki i kultury, współorganizowane z Kołem Metodologicznym Historyków UMCS;

- Public History i technologie cyfrowe w perspektywie interdyscyplinarnych przedsięwzięć zadaniowych i projektów badawczo-edukacyjnych;

- Wdrażanie badań historycznych w obszarze przemysłów kreatywnych we współpracy z Centrami badawczo-rozwojowymi;

- Kontynuacja przedsięwzięć projektowych w perspektywie alternatywnych podejść do badań historycznych;

- Kreowanie forum dyskusji wokół zagadnień związanych z obecną sytuacją nauki historii, edukacji historycznej, public history, polityki historycznej w Europie Środkowo-Wschodniej.

Przy Zakładzie działa Koło Metodologiczne Historyków UMCS, którego inicjatorką i opiekunką jest dr Ewa Solska. Jego działalność, poza obszarem zagadnień meta-nauki i teorii historii, lokalizuje się w przestrzeni public history, otwarte jest zatem wszelkie propozycje upraktyczniania wiedzy historycznej. W tym kontekście, z wykorzystaniem zwłaszcza nowych mediów, działań performatywnych i przedsięwzięć promocyjnych w przestrzeni miejskiej koncentruje się na projektach badawczych, edukacyjnych i popularyzacyjnych w zakresie studiów nad pamięcią historyczną, 
historią w Internecie, nowoczesnymi sposobami organizacji wiedzy. Wspóluczestniczy w projekcie „Historie alternatywne”, współpracuje z lubelskim oddziałem Towarzystwa Historiograficznego, Zakładem Metodologii Historii UMCS i centrum BadawczoRozwojowym e-Humanistyka przy UMCS - obecnie w perspektywie projektu badawczo-wdrożeniowego „TV-e-Historia”. Organizuje cykliczne panele dyskusyjne, wykłady skoncentrowane na metodologicznych aspektach nauk humanistycznych oraz współczesnych trendów, zjawisk i procesów w przestrzeni nauki w ogóle, a także na problemach dziedzictwa kulturowego regionu Lubelszczyzny i Europy. W 2012 roku Koło zostało laureatem „Konkursu na projekt” organizowanego przez prof. Lenę Kolarską-Bobińską, ówczesną poseł do Parlamentu Europejskiego. W nagrodę jego członkowie wzięli udział w kilkudniowym wyjeździe do Brukseli w ramach wizyty studyjnej do Parlamentu Europejskiego. Dzięki wspólpracy z prof. Kolarską-Bobińską zorganizowało też konkurs na krótki film historyczny o tematyce regionalnej dla uczniów szkół ponadgimnazjalnych z województwa lubelskiego pt. „Stąd jestem - tu zostaję” oraz debatę pt. „Czy i jak studiować historię regionalną”. Prowadziło także pierwsze w Polsce warsztaty historii intermedialnej: „Digital Storytelling”.

Pracownicy Zakładu Metodologii Historii UMCS razem ze skupionymi wokół niego doktorantami i studentami efektywnie współpracują z wieloma ośrodkami metodologicznymi i historiograficznymi w Polsce i na świecie. Z powodzeniem rozwijają i wdrażają w życie ideę prof. Jerzego Topolskiego o konieczności prowadzenia teoretycznej refleksji nad akademicką historiografią (praktyką badawczą historyków) poszerzając ją o namysł nad public history. 
